\title{
PROBLEM SOLVING PATOLOGI SOSIAL DALAM PERSPEKTIF ISLAM
}

\author{
Siti Badi'ah \\ Universitas Islam Negeri RadenIntan Lampung \\ badiab@radenintan.ac.id
}

Abstract

The development of science and technology, the minimum of employment and the decline in the level of education are very influential on the emergence of social problems in society. Social problems in the community are often referred to as "social pathology." Community disease is the behavior of members of the community which can lead to unrest and insecurity in people's lives. Community diseases in the social community today are increasingly prevalent in the community, especially the local government and very disturbing people who live in the area. Examples of community diseases are gambling, fighting or brawls, drug or drug abuse, alcobolism or drunkenness, prostitution, corruption, and many more public diseases that occur in society today. social is one of the problems that is considered by Islam, various kinds of problems have been explained in the Qur'an to solve this problem, for example giving punishment to people for theft, drunkenness, killing, etc. is a reward for people who do something mass ah which is contrary to Islamic law. This research is an attempt to look at the problem of community diseases in the eyes of the Qur'an. This study has three focus problems, namely: first; efforts to see the type of society's illness in the view of the Qur'an, second; see things that are the background to the emergence of social pathology, and third; efforts to find solutions/ knowledge of social pathology in the view of the Qur'an.

\section{Abstrak}

Perkembangan ilmu pengetabuan dan teknologi, minimalnya lapangan pekerjaan dan menurunnya tingkat pendidikan sangat berpengarub terbadap munculnya masalah-masalah sosial dalam masyarakat. Masalah-masalah sosial dalam 
masyarakat tersebut sering disebut sebagai "patologi sosial". Penyakit Masyarakat adalah perilaku dari anggota masyarakat yang dapat menimbulkan keresahan dan ketidaktentraman dalam kehidupan masyarakat.Penyakit masyarakat di kalangan sosial masyarakat saat ini sudah semakin marak di kalangan masyarakat khususnya pemerintah daerah dan sangat meresabkan masyarakat yang tinggal di daerah tersebut.Contoh dari penyakit masyarakat adalah perjudian, perkelabian atau tawuran, penyalah gunaan narkoba atau NAPZA, alkoholisme atau mabuk-mabukan, pelacuran, korupsi, dan masib banyak lagi penyakit masyarakat yang terjadi di masyarakat saat ini.Patologi sosial merupakan salah satu masalah yang diperhatikan oleh Islam, berbagai macam persoalan telah dijelaskan dalam al-Qur'an untuk. memecabkan masalab ini, misalnya memberikan bukuman bagi orang melakukan pencurian, mabuk mabukan, membunuh, dan lain sebagainya merupakan ganjaran bagi orang yang melakukan suatu masalah yang bertentangan dengan bukum Islam.Penelitian ini merupakan upaya melihat masalah penyakit-penyakit masyarakat dalam kacamata al-Qur'an. Penelitian ini memiliki tiga fokus masalah yaitu: pertama; upaya untuk melihat jenis penyakit masyarakat dalam pandangan al-Qur'an, kedua; melihat hal-hal yang menjadi latar belakang munculnya patologi sosial, dan ketiga; upaya untuk. menemukan solusi/pengatabuan terbadap patologi sosial menurut pandangan al-Qur'an.

Keywords : Problem Solving Social Pathology; the Qur'an

\section{A. Pendahuluan}

Perubahan sosial merupakan salah satu cabang kajian dari ilmu sosial. Perubahan sosial ini menurut para sosiolog ada dua yaitu perubahan sosial ke arah positif dan perubahan sosial kearah negatif. Perubahan sosial kearah positif bisa dilihat dari berkembangnya ilmu pengetahuan, adanya pembaharuan yang ada di masyarakat yang tidak merugikan berbagai pihak dan lain sebagainya.

Adapun perubahan sosial kearah negatif bisa dilihat dari segi bentuk masalah yang terjadi di masyarakat dan itupun sangat merugikan dan membahayakan masyarakat lainnnya. Perubahan sosial ke arah negatif inilah yang disebut dengan patologi sosial atau penyakit masyarakat, berbagai macam patologi sosial ini adalah seperti kemiskinan, perampokan dan sejenisnya, meminum minuman keras, gelandangan, anak jalanan, judi dan lain sebagainya. 
Penyakit masyarakat atau disebut juga dengan patologi sosial merupakan fenomena yang sangat penting di perhatikan oleh siapapun. Patologi sosial adalah semua tingkah laku yang bertentangan dengan norma kebaikan, stabilitas lokal, pola kesederhanaan, moral, hak milik, solidaritas kekeluargaan, hidup rukun bertetangga, disiplin, kebaikan dan hukum formal. Berbagai macam kerugian termasuk terancamnya jiwa seseorang merupakan salah satu dampak patologi sosial.

Kondisi ekonomi yang morat marit dan harga barang yang selalu membumbung tinggi merupakan salah satu penyebab dari timbunya masalah penyakit masyarakat. Namun, dalam perkembangannya, masalah penyakit masyarakat sekarang ini sudah semakin menjadi-jadi, yang mana berbagai macam bentuk perbuatan yang bertentangan dengan hukum dan norma agama serta adat sudah menjadi kebiasaan masyarakat.

Di era globalisasi dan informasi ini, perubahan masyarakat lebih cepat jika dibandingkan dengan pemecahan permasalahan masyarakat. Manusia sekarang ini tengah disibukkan dengan kesibukan oleh kebutuhan yang semakin kompetitif bersaing dengan aneka ragam tantangan bahkan bekorban raga serta jiwa, dan juga termasuk perkembangan ilmu pengetahuan yang akan melahirkan berbagai macam penemuan dan pembaharuan dibidang teknologi sampai dengan informasi yang nantinya akan mengajak manusia berubah untuk mengikuti kepentingan diri sendiri.

Indonesia sedang mengalami perubahan sosial yang sangat cepat akibat pertemuan dua kebudayaan masyarakat dunia. Hal ini memungkinkan karena perkembangan teknologi yang begitu cepat. Hakikat perubahan dari percepatan itu mempunyai konsekwensikonsekwensi pribadi, psikologis dan sosial. Hakikat perubahan adalah faktor kekuatan yang dapat menjadi integrasi dan disorganisasi. Pertentangan dua kekuatan ini perlu dicermati. Sementara itu dalam konvensi kesehatan jiwa nasional II di Jakarta membahas tentang kemiskinan.

Menurut pembukaan UUD 1945, dijelaskan bahwa fakir miskin dan anak-anak terlantar di pelihara oleh negara. Namun, bentuk pelaksanan dan penerapan Undang-Undang ini tidak begitu jelas adanya sehingga orang-orang yang di jelaskan dalam kalimat 
dalam pembukaan UUD 1945 ini masih banyak telihat dengan kehidupan mereka yang sangat menyedihkan.

Berbagai macam bentuk patologi sosial yang diungkapkan oleh para pakar ilmu sosial, seperti yang telah dijelaskan diatas, merupakan masalah yang sering terjadi di negeri ini, namun belakangan ini, berbagai macam bentuk patologi sosial ini bukan saja dilakukan oleh masyarakat miskin, namun para pejabat juga telah membuat penyakit kepada masyarakat, seperti melakukan KKN, yang sangat merugikan masyarakat dan negara.

Perkembangan ilmu pengetahuan dan teknologi yang ikut serta mengancam jiwa masyarakat, yang nantinya menimbulkan berbagai macam masalah negatif yang meresahkan masyarakat seperti adanya tayangan-tanyangan yang membangkitkan gairah seksual manusia. Masalah pornografi yang akan menyebabkan terjadinya perzinaan, pemerkosaan, prostitusi pelecehan seksual terhadap anak kecil dan bahkan akan menimbulkan perbuatan lesbian dan homo seksual merupakan masalah yang sangat meresahkan stabilitas kehidupan bermasyarakat, sehingga masalah ini harus dicegah sedini mungkin agar tidak menjalar kepada masyarakat lain.

Al-Qur'an merupakan kitab suci umat Islam dan juga merupakan Dasar hukum Islam dan Sumber syariat Islam yang memiliki banyak manfaat bagi umat manusia. Al-Qur'an diturunkan sebagai petunjuk bagi seluruh manusia melalui malaikat Jibril kepada Nabi Muhammad SAW. Sebagai Rasul yang dipercaya menerima mukjizat Al-Qur'an, Nabi Muhammad SAW menjadi penyampai, pengamal, serta penafsir pertama dari Al-Qur'an.Kandungan atau kajian al-Qur'an sangat holistik dan komprehensif.

Pertanyaan besar muncul kepada umat Islam masa kini, apakah umat Islam masih berpegang teguh pada al-Qur'an atau hanya menyimpannya sebagai formalitas, jika memang al-Qur'an masih menjadi pedoman umat Islam, mengapa kandungan al-Qur'an tidak diaktualisasikan.Isyarat- isyarat yang termaktub dalam al-Qur'an seolah-olah hanya hal yang sepintas selalu. 


\section{B. Patologi Sosial dalam Al-Qur'an}

Pada awal ke-19 dan awal abad 20-an, para sosilog mendefinisikan patologi sosial sebagai semua tingkah laku yang bertentangan dengan norma kebaikan, stabilitas lokal, pola kesederhanaan, moral, hak milik, solidaritas kekeluargaan, hidup rukun bertetangga, disiplin, kebaikan, dan hukum formal. Secara etimologis, kata patologi berasal dari kata Pathos yang berarti disease/penderitaan/penyakit dan Logos yang berarti berbicara tentang/ilmu.Jadi, patologi adalah ilmu yang membicarakan tentang penyakit atau ilmu tentang penyakit.Maksud dari pengertian diatas bahwa patologi adalah ilmu yang membicarakan tentang asal usul dan sifat-sifatnya penyakit.Konsep ini bermula dari pengertian penyakit di bidang ilmu kedokteran dan biologi yang kemudian diberlakukan pula untuk masyarakat karena menurut penulis google bahwa masyarakat itu tidak ada bedanya dengan organisme atau biologi sehingga dalam masyarakatpun dikenal dengan konsep penyakit.Sedangkan kata sosial adalah tempat atau wadah pergaulan hidup antar manusia yang perwujudannya berupa kelompok manusia atau organisasi yakni individu atau manusia yang berinteraksi / berhubungan secara timbal balik bukan manusia atau manusia dalam arti fisik.Tetapi, dalam arti yang lebih luas yaitu comunity atau masyarakat. Maka pengertian dari patologi sosial adalah ilmu tentang gejala-gejala sosial yang dianggap "sakit" disebabkan oleh faktor-faktor sosial atau Ilmu tentang asal usul dan sifat-sifatnya, penyakit yang berhubungan dengan hakekat adanya manusia dalam hidup masyarakat. ${ }^{1}$ Sementara itu menurut teori anomi bahwa patologi sosial adalah suatu gejala dimana tidak ada persesuaian antara berbagai unsur dari suatu keseluruhan, sehingga dapat membahayakan kehidupan kelompok, atau yang sangat merintangi pemuasan keinginan fundamental dari anggota anggotanya, akibatnya pengikatan sosial patah sama sekali.

Ukuran dalam sosiologi suatu maslah merupakan patologi sosial adalah:

1. Tidak adanya kesesuaian antara ukuran/ nilai- nilai dengan kenyataan- kenyataan/ tindakan- tindakan sosial;

${ }^{1}$ Kartini Kartono, Patologi Sosial, (Jakarta: PT. Raja Grafindo Persada, 2005), h. 4. 
2. Sumber- sumber sosial dari masalah sosial, yaitu merupakan akibat dari suatu gejala sosial atau bukan, yang menyebabkan masalah sosial;

3. Pihak- pihak yang menetapkan apakah suatu kepincangan merupakan gejala sosial atau tidak, tergantung dari karakteristik masyarakatnya;

4. Manifest social problems dan latent social problems;

5. Perhatian masyarakat dan masalah sosial sosial;

6. Sistem nilai dan dapatnya suatu masalah sosial diperbaiki. ${ }^{2}$

Beberapa masalah sosial yang dianggap sebagai patologi sosial adalah tergantung dari sistem nilai sosial masyarakat tersebut. Ada beberapa persoalan yang dihadapi oleh masyarakat- masyarakat yang pada umumnya sama yaitu sebagai berikut:

1. Kemiskinan; diartikan sebagai suatu keadaan dimana seseorang tidak sanggup memelihara dirinya sendiri sesuai dengan taraf kehidupan kelompok dan juga tidak mampu memanfaatkan tenaga mental maupun fisiknya dalam kelompok tersebut.

2. Kejahatan; disebabkan karena kondisi- kondisi dan prosesproses sosial yang sama, yang menghasilkan perilaku- perilaku sosial lainnya;

3. Diorganisasi keluarga; perpecahan keluarga sebagai suatu unit karena anggota- anggotanya gagal memenuhi kewajibankewajibannya yang sesuai dengan peranan sosialnya;

4. Masalah generasi muda dalam masyarakat modern; pada umumnya ditandai oleh dua ciri yng berlawanan, yaitu keinginan untuk melawan misalnya dalam bentuk radikalisme, delinkuaensi dan sebagainya. Sikap apatis misalnya penyesuaian yang membabi buta terhadap ukuran moral generasi tua;

5. Peperangan; peperangan mungkin merupakan masalah sosial paling sulit dipecahkan sepanjang sejarah kehidupan manusia.

6. Pelanggaran terbadap norma-norma masyarakat seperti pelacuran, delinkuensi anak- anak, alkoholisme, homoseksualitas;

7. Masalah kependudukan;

8. Masalah lingkungan bidup;

9. Birokarasi;

${ }^{2}$ Soerjono Soekanto, Sosiologi Suatu Pengantar, (Jakarta: PT. Rajagrafindo Persada, 2015), Cet ke-47, h. 319. 
Dalam Islam ada dua bentuk kondisi kehidupan yang satu sama lain bertolak belakang. Ada kebaikan ada keburukan.Kebaikan dan keburukan yang diberikan dan diciptakan oleh Allah Swt, agar manusia mampu berfikir secara baik dan menentukan pilahan hidup yang selalu berhadapan dengan resiko. Resiko dimaksud adalah akan mendatagkan efek baik bersifat positif maupun negatif. Seseorang akan memperoleh sesuatu yang bersifat positif berupa kebaikan mana kala ia memulai dengan hal-hal positif. Positif dimaksud adalah halhal yang dipandang baik secara syar $`$. Sebaliknya jika kejahatan yang dilakukan oleh manuisa maka kejahatan itulah dengan berbagai konsekwensi logis yang diterima dari kejahatan yang dilakukannya. Kejahatan secara pribadi yang tidak menganggu pola hidup bermasyarakat disebut dengan masalah sosial dan kalau sudah menganggu ketenagan dan kesejahteraan orang lain maka berubahlah posisinya menjadi patologi sosial.

Dalam konteks al-Qur`an term masalah sosial dan patologi sosial dikenal denngan istilah al- fasiq al- Fabsya; al- munkar, alMąhlum, al-bagy, as-su', al-Khamar, al-maysir, al-anshab, al-azhlam, alzina, al-miskin, al-bathil, al-Riba, ghazwah al-Fiker wa al- sukara. Semua masalah ini tidak semua dikatakan menjadi patologi sosial.

Al-Fasiq; Fasiq, orang yang menyimpang dari kebenaran, melakukan perbuatan maksiat, atau mengerjakan dosa besar.Pengertian fasiq secara esensial terkandung dalam kata kafir. Sehingga disepakati dalam teologi Islam bahwa setiap kafir pasti fasiq.(Harun Nasution, Ensiklopedia Islam Indonesia, (jakarta: Djambatan: 1992),h.243.

Al-Fahsya', (pengertian, bentuk, pemicu, akibat, dan solusi). al- munkar, al- bagyn, as-su', al-Khamar, al-maysir, al-anshab, alazhlam, al-zina, al-miskin, al-bathil, al-Riba`, ghazwah al-Fikr wa Fahisyah diartikan sebagai kejahatan seperti ditemukan dalam surat An-Nisa ayat 15, al-Isra` 32, An-Nisa` 25, dan Ali Imran 135, Fahisyah atau kekejian / kejahatan dimaksud dari ayat-ayat di atas termasuk perbuatan dan tindakan melakukan zina dan riba. Karena zina dan riba berefek negatif dan menganggu kepada orang lain. Hal ini ditegaskan dalam surat Ali Imran ayat 135.

Artinya: "Dan (juga) orang-orang yang apabila mengerjakan perbuatan keji atau Menganiaya diri sendiri, mereka ingat akan Allah, lalu memohon 
ampun terhadap dosa-dosa mereka dan siapa lagi yang dapat mengampuni dosa selain dari pada Allab? dan mereka tidak meneruskan perbuatan kejinya itu, sedang mereka mengetabui".

M. Qurais Shihab mengemukakan bahwa kata Fahisyah yang diterjemah-kan dengan perbuatan keji diartikan dengan dosa besar. Sedangkan menganiaya diri sendiri diartikan sebagai dosa atau pelanggaran secara umum termasuk di dalamnya dosa besar. Muhammad Sayyid Thantawi sebagaimana yang dikutip Quraihs Shihab juga menjelaskan bahwa perbuatan keji dan menganiaya diri merupakan dua sisi dari setiap kedurhakaan.Setiap perbuatan keji yang dilakukan seseorang berakibat penganiayaan atas dirinya, demikian sebaliknya.

Masalah kekejian seperti yang dikemukan di atas berawal dari diri dan bendanpak kepada diri pelaku sewaktu wakru akan menjadi masalah sosial yang patologis manakala berakibat buruk dan menganggu tatanan sosial dan norma yang berlaku dalam kehidupan sosial. Zina dan riba merupakan salah satu bentuk kekejian yang dijelaskan dalam penjelasan mufassir diatas karena efek yang ditimbulkan oleh perbuatan tersebut sangat berpengaruh dalam kehidupan bermasyarakat. Akibat buruk dari perbuatan zina misalnya akan melahirkan generasi yang hilang garis keturunannanya, hilang masa depan dan nama baiknya. Begitu pula dengan riba akan meresahkan kehidupan secara ekonomis dalam masyarakat.

Kata sabila, dikemukakan dalam surat Al-Isra` ayat 32. Dalam surat tersebut dipahami oleh sementara ulama dalam arti jalan yang buruk karena ia mengantar menuju neraka. Ibnu `Asyur memahami kata sabila dalam arti perbuatan yang menjadi kebiasaan seseorang.Thabathaba $i$ memahaminya dalam arti jalan untuk mempertahankan kehidupan.Ulama ini menghubungkan permasalahannya dengan Qs al-Ankabut ayat 29 yang menyipati kebiasaan buruk kaum Luth as yakni melakukan homoseksual sebagai Taqta una sabil yaitu memutus jalan. Jalan yang mereka putus adalah jalan kelanjutan keturunan karena kelakuan tersebut tidak menghasilkan keturunan dan kelanjutan jenis manusia. Berbeda dengan perrzinahan, yang melakukannya mendapat keturunan atau dapat memperoleh anak dan kelanjutan jenispun dapat terlaksana akan tetapi jalan itu adalah jalan yang sangat buruk. Keburukan jalan yang ditempuh adalah dengan melakukan pelanggaran norma yang 
berlakudan merusak tatanan yang disepakati oleh suatu komonitas. Disamping itu akibat dari perbuatan kejahatan atau perbuatan buruk akan munculnya penyakit yang membahayakan dan meresahkan masyarakat seperti spilis dan sebaginya.

Dengan demikian dapat dipahami bahwa al-Qur`an sebagai sumber pokok ajaran Islam mengemukakan berbagai masalah atau problem sosial yang sebagian orang menyebutnya dengan patologi sosial dalam berberapa ayat seperti yang dikemukakan pada pembahasan sebelumnya juga pada ayat lain dikemukan seperti terdapat dalam surat al-Maidah ayat 90-92, surat al-Baqarah: 219, anNisa': 43 (masalah perjudian dan mabuk-mabukan). an-Nisa': 16, 2425, al-Maidah; 5, an-Nur; 26, 33, al-A'raf; 80-82.

Artinya: "Hai orang-orang yang beriman, Sesunggubnya (meminum) khamar, berjudi, (berkorban untuk) berhala, mengundi nasib dengan panah, adalab Termasuk perbuatan syaitan. Maka jaubilah perbuatanperbuatan itu agar kamu mendapat keberuntungan.Sesunggubnya syaitan itu bermaksud bendak menimbulkan permusuban dan kebencian di antara kamu lantaran (meminum) khamar dan berjudi itu, dan menghalangi kamu dari mengingat Allah dan sembahyang; Maka berhentilah kamu (dari mengerjakan pekerjaan itu).dan taatlah kamu kepada Allah dan taatlah kamu kepada Rasul-(Nya) dan berhati-hatilah. jika kamu berpaling, Maka ketabuilah bahwa Sesunggubnya kewajiban Rasul Kami, hanyalah menyampaikan (amanat Allab) dengan terang”. (QS. Al- Maidah : 90-93).

Artinya: "Mereka bertanya kepadamu tentang khamar dan judi. Katakanlah: "Pada keduanya terdapat dosa yang besar dan beberapa manfaat bagi manusia, tetapi dosa keduanya lebib besar dari manfaatnya". dan mereka bertanya kepadamu apa yang mereka nafkabkan. Katakanlah: " yang lebih dari keperluan." Demikianlah Allah menerangkan ayatayat-Nya kepadamu supaya kamu berfikir". (QS. Al- Baqarah : 219)

Artinya: "Hai orang-orang yang beriman, janganlah kamu shalat, sedang kamu dalam Keadaan mabuk, sehingga kamu mengerti apa yang kamu ucapkan, (jangan pula hampiri mesjid) sedang kamu dalam Keadaan junub, terkecuali sekedar berlalu saja, bingga kamu mandi. dan jika kamu sakit atau sedang dalam musafir atau datang dari tempat buang air atau kamu telah menyentuh perempuan, kemudian kamu tidak 
Siti Badi'ah

mendapat air, Maka bertayamumlah kamu dengan tanah yang baik (suci); sapulah mukamu dan tanganmu. Sesunggubnya Allah Maba Pema'af lagi Maha Pengampun”. (QS. An-Nisa: 43)

Artinya: "Dan terhadap dua orang yang melakukan perbuatan keji di antara kamu, Maka berilab bukuman kepada keduanya, kemudian jika keduanya bertaubat dan memperbaiki diri, Maka biarkanlah mereka. Sesungguhnya Allah Maba Penerima taubat lagi Maba Penyayang". (QS. An-Nisa': 16)

Artinya: "Dan (diharamkan juga kamu mengawini) wanita yang bersuami, kecuali budak-budak yang kamu miliki[282] (Allah telah menetapkan bukum itu) sebagai ketetapan-Nya atas kamu. dan Dihalalkan bagi kamu selain yang demikian [283] (yaitu) mencari isteri-isteri dengan bartamu untuk dikawini bukan untuk berzina. Maka isteri-isteri yang telah kamu nikmati (campuri) di antara mereka, berikanlab kepada mereka maharnya (dengan sempurna), sebagai suatu kewajiban; dan Tiadalah mengapa bagi kamu terbadap sesuatu yang kamu telah saling merelakannya, sesudah menentukan mahar itu. Sesunggubnya Allab Maha mengetahui lagi Maha Bijaksana.

Barangsiapa diantara kamu (orang merdeka) yang tidak cukup perbelanjaannya untuk mengawini wanita merdeka lagi beriman, ia boleh mengawini wanita yang beriman, dari budak-budak yang kamu miliki. Allah mengetahui keimananmu; sebahagian kamu adalah dari sebahagian yang lain [285], karena itu kawinilah mereka dengan seizin tuan mereka, dan berilah maskawin mereka menurut yang patut, sedang merekapun wanita-wanita yang memelihara diri, bukan pezina dan bukan (pula) wanita yang mengambil laki-laki lain sebagai piaraannya; dan apabila mereka telah menjaga diri dengan kawin, kemudian mereka melakukan perbuatan yang keji (zina), Maka atas mereka separo bukuman dari bukuman wanita-wanita merdeka yang bersuami. (Kebolehan mengawini budak) itu, adalah bagi orang-orang yang takut kepada kemasyakatan menjaga diri (dari perbuatan zina) di antara kamu, dan kesabaran itu lebih baik bagimu.dan Allah Maha Pengampun lagi Maha Penyayang”. (QS. An-Nisa:24-25)

Artinya: "Pada hari ini Dibalalkan bagimu yang baik-baik. makanan (sembelihan) orang-orang yang diberi Al kitab itu halal bagimu, dan makanan kamu balal (pula) bagi mereka. (dan Dibalalkan 
mangawini) wanita yang menjaga kehormatan diantara wanita-wanita yang beriman dan wanita-wanita yang menjaga kehormatan di antara orang-orang yang diberi Al kitab sebelum kamu, bila kamu telah membayar mas kawin mereka dengan maksud menikabinya, tidak dengan maksud berzina dan tidak (pula) menjadikannya gundikgundik. Barangsiapa yang kafir sesudah beriman (tidak menerima bukum-hukum Islam) Maka hapuslah amalannya dan ia di hari kiamat Termasuk orang-orang merugi”.

$$
\text { (QS. Al-Maidah : 5) }
$$

Artinya: 'Wanita-wanita yang keji adalah untuk laki-laki yang keji, dan laki-laki yang keji adalab buat wanita-wanita yang keji (pula), dan wanita-wanita yang baik adalah untuk laki-laki yang baik dan lakilaki yang baik adalah untuk wanita-wanita yang baik (pula). mereka (yang ditudub) itu bersih dari apa yang ditudubkan oleh mereka (yang menuduh itu). bagi mereka ampunan dan rezki yang mulia (surga)". (QS. An-Nur: 26)

Artinya: "Dan orang-orang yang tidak mampu kawin hendaklah menjaga kesucian (diri)nya, sehingga Allah memampukan mereka dengan karunia-Nya. dan budak-budak yang kamu miliki yang memginginkan perjanjian, hendaklah kamu buat Perjanjian dengan mereka, jika kamu mengetahui ada kebaikan pada mereka, dan berikanlah kepada mereka sebahagian dari harta Allab yang dikaruniakan-Nya kepadamu. dan janganlah kamu paksa budakbudak wanitamu untuk melakukan pelacuran, sedang mereka sendiri mengingini kesucian, karena kamu hendak mencari Keuntungan duniawi. dan Barangsiapa yang memaksa mereka, Maka Sesunggubnya Allah adalah Maba Pengampun lagi Maha Penyayang (kepada mereka) sesudah mereka dipaksa itu”. (QS. An-Nur: 33)

Artinya: "Dan (kami juga telah mengutus) Luth (kepada kaumnya). (ingatlah) tatkala Dia berkata kepada mereka: "Mengapa kamu mengerjakan perbuatan faabisyah itu[551], yang belum pernah dikerjakan oleh seorangpun (di dunia ini) sebelummu?"

Sesunggubnya kamu mendatangi lelaki untuk melepaskan nafsumu (kepada mereka), bukan kepada wanita, malah kamu ini adalah kaum yang melampani batas.jawab kaumnya tidak lain banya mengatakan: "Usirlah mereka (Luth dan pengikut-pengikutnya) dari 
kotamu ini; Sesunggubnya mereka adalah orang-orang yang berpurapura mensucikan diri." (QS. al-A'raf: 80-82)

Faktor penyebab terjadinya kehidupan sosial yang patologis, Muhammad Sayyid al-Wakil mengungkapkan bahwa kaum muslimin telah jauh dari sember-sember keagungan dan menjauh dari pedoman mereka, sehingga mereka terhina dan tersesat. Mereka tidak lagi menfungsikan akalnya dan berpaling dari nilai-nilai rohani sehingga kehilangan seluruh kebaikan dan kemuliaan. Rafiuddin dan Maman Abd Jalil menjelaskan bahwa penyebab dari permasalahan ini adalah:

1. Problema akidah akhlak serta syari'ah, dengan banyaknya penyimpangan akidah dan syariah akan melahirkan gerakan kelompok-kelompok (firkah-firkah) yang sangat mengganggu umat Islam lainnya, karena itu sumber Islam yang aslinya yaitu al-Qur'an harus benar-benar dipelihara secara sunggguh-sungguh agar terlepas dari belengggu kesulitan.

2. Problematika ukuwah Islamiyyah. Persaudaraan Islam sangat membantu dalam kehidupan bermasyarakat supaya kehidupan mereka menjadi aman, tentram bahkan keadilan dan kemakmuran akan terjalin dengan adanya persaudaraan. Namun karena dipengaruhi oleh sedikit perbedaan faham dalam dan masalah keagamaan, maka timbulah aliran-aliran sehingga timbul ketimpangan diantara mereka. Hal ini mennyebabkan anntara satu aliran dengan aliran lainnya timbul perpecahan bahkan permusuhan diantara mereka.

3. Problematika generasi. Generasi muda adalah penerus estafet perjuangan bangsa serta agama. Dalam perkembanganya, dan bahkan sampai saat sekarang ini generasi muda adalah harapan serta tumpuan untuk meneruskan cita-cita bangsa dan agama. Di sini dibutuhkan peranan orang tua serta bimbingan seorang guru untuk melanjutkan cita-cita tersebut, namun kurangnya peranan orang tua sebagai guru pertama bagi mereka, akan menyebabkan mereka berjalan ke jalan yang sebenarnya tidak mereka tempuh, sehingga timbul kejahatan-kejahatan yang ditimbulkan oleh generasi muda. 


\section{Problem Solving Patologi Sosial Dalam al-Qur'an.}

Problem Solving terhadap berbagai patologi sosial yang berkembang di tengah masyarakat yang pertama adalah dengan pemantapan kalimah tauhid ini bermakna pendidikan membentuk pemikiran, perasaan serta penanaman nilai-nilai keimanan yang dinyatakan oleh Rasulullah Sesungguhnya kesadaran manusia tentang perwujudan, kebesaran, kekuasaan dan keesaan Allah SW'T, tentunya akan membentuk keyakinan yang tinggi terhadap petunjukpetunjukNya.

Dalam konteks yang sama, perkara utama yang perlu dilakukan oleh seorang muslim ialah memastikan dirinya bersih dari kekufuran atau tanda-tanda kekufuran kepada Allah dan Rasulnya. Kemudian, ia harus memastikan dirinya terlepas dari sifat-sifat kemunafikan, Kemunafikan dalam amalan ialah melakukan akhlakakhlak orang yang munafik seperti tidak mematuhi janji, membiasakan diri dengan berdusta dan bersifat khianat, tidak melakukan apa yang dilarang oleh Alloh, tidak menyalahi perintah Allah, dan menghindari diri dari segala kejahatan lahir dan batin. Pembangunan akhlak bermula dengan kebiasaan sholat, zakat dan infak, puasa, membaca al- Qur'an, dzikir, memikirkan penciptaan Allah, mengingat akan kematian dan memendekkan angan-angan, muraqabah, muhasabah, mujahadah dan mu'atabah, jihad, amal makruf dan nahi mungkar, dedikasi dan bersifat tawaddu', mengenali tipu daya syaitan terhadap manusia serta menangkisnya, mengenal jenis-jenis penyakit hati serta mengetahui cara-cara merawatnya.

Problem Solving terhadap Patologi Sosial yang kedua adalah : Pembentukan akhlak sejak dini sangatlah penting, kalau dalam Islam dimulai dengan pengukuhan akidah melalui ikrar bahwa tidak ada Tuhan sebenarnya yang disembah kecuali Allah dan Muhammad adalah Rasululloh SAW. Bagi anak yang baru lahir penanaman ini dimulai dengan azan dan iqamat.Anak dilatih dengan budaya hidup beragama Islam oleh orang tuanya. Apabila lidah anak-anak sudah bisa berbicara, mereka dilatih menyebut nama Allah dan ayat singkat seperti:

Artinya: "Dan katakanlah: "Segala puji tertentu bagi Allab yang tiada mempunyai anak, dan tiada bagiNya sekutu dalam urusan kerajaanNya, dan tiada bagiNya penolong disebabkan sesuatu 
kelemahanNya; dan hendaklah engkan membesarkan serta memuliakanNya dengan bersungguh-sunggub!"

Menurut Syaikh Abdul Rahman Al Midani; akhlak manusia memang dapat berkembang dan dibentuk dengan berbagai cara. Antara lain melalui: sejak dini latihan melaksanakan amalan menjernihkan batin, hidup dalam lingkungan yang soleh, qudwah hasanah (teladanilah Rosullullah Muhammad SAW). Di samping itu, media massa merupakan satu mekanisme yang mempunyai pengaruh yang amat besar dan berkesan di dalam pembentukan keperibadian manusia. Ia merupakan agen sosialisasi dan memainkan peranan penting di dalam menanam dan menggalakkan amalan-amalan berakhlak di dalam masyarakat. Media massa mampu mencorakkan hati dan budipekerti. Media massa harus terbebas dari paham sekularisme, budaya komersial yang melampau, paham kebendaan dan dorongan untuk hidup secara mewah dan berfoya-foya.

Problrm Solving terhadap uapaya pencegahan kemiskinan adalah dengan membangun sistem ekonomi yang adil. Salah satu sebab terjadinya kemiskinan sebagaimana disebutkan diatas, adalah karena system perekonomian yang berlaku dimasyarakat adalah system ekonomi yang saling mematikan, menghalalkan segala cara dan penuh persaingan. Dalam keadaan ekonomi yang demikian itu, maka pihak yang memiliki modal yang besar, memiliki sarana, ilmu dan teknologi lebih dapat bersaing dibanding golongan pedagang kecil yang tidak memiliki modal yang besar dan lainnya itu. Untuk itu akibatnya pedagang kecil dari golongan miskin dengan mudah dapat dimatikan oleh golongan ekonomi yang kuat.

Adanya prinsip keadilan yang diwujudkan dengan prinsip pemerataan ekonomi yang adil ini ditegaskan oleh Ibn Hazm sebagaimana dikutip oleh Amien Rais didalam bukunya Taubid Sosial mengatakan bahwa kalauditengah masyarakat ada kelompok kaya dan miskin, sudah jadi kewajiban kelompok kaya tadi untuk melakukan proses pemerataan sosial ekonomi ke seluruh masyarakat. Dan menjadi hak kelompok orang-orang dibawah, miskin untuk mengambil haknya dari kelompok kaya.Didalam al-Quran prinsip tentang keadilan disini ditegaskan didalam surat al-Hadid (57) ayat 25: 
Sungguh, kami telah mengutus rasul-rasul kami, dengan bukti-bukti yang nyata dan kami turunkan bersama mereka Kitab dan neraca (keadilan)agar manusia dapat berlaku adil... (QS. Al-Hadid, 57:25).

\section{Penutup}

Patologi sosial merupakan salah satu masalah yang diperhatikan oleh Islam, berbagai macam persoalan telah dijelaskan dalam al-Qur'an untuk memecahkan masalah ini, misalnya memberikan hukuman bagi orang melakukan pencurian, mabuk mabukan, membunuh, dan lain sebagainya merupakan ganjaran bagi orang yang melakukan suatu masalah yang bertentangan dengan hukum Islam. 


\section{Daftar Pustaka}

Cik Hasan Bisri, Model Penelitian Agama dan Dinamika Sosial, Jakarta: PT RajaGrafindo Persada, 2002.

Dadang Kahmad, Sosiologi Agama, Bandung: Rosda Karya, 2009.

Emilia Setyoningtyas, Kamus Trendy Bahasa Indonesia, Surabaya: Apollo Lestari, t.t.

Hamid Patilima, Metode Penelitian Kualitatif, Bandung: CV. Alfabeta, 2007.

Howard M. Federspiel, Kajian al-Qur'an di Indoensia: Dari Mahmand Yunus hingga Quraish Shibab, Bandung: Mizan, 1996.

Ibn Katsir, Lubab al-Tafsir Min Tafsir Ibnu Katsir, Terjemah, Jakarta: Pustaka Imam al-Syafi'i, 2012.

Jalaludin Rakhmat, Islam Aktual, Bandung: Mizan, 1991.

Jim Ife dan Frank Tesoriero, Community Development, Yogyakarta: Pustaka Pelajar, 2014.

Kartini Kartono, PatologiSosial 1, Jakarta: Rajawali Grafindo, 2013. , Patologi Sosial 2, Kenakalan Remaja, Jakarta: Rajawali Grafindo, 2013. Jakarta: RajawaliGrafindo, 2013.

Kementerian Agama RI, Al-Qur'an Dan Tafsirnya (Edisi Revisi), Jakarta: Lentera Abadi, 2011.

Kementerian Agama RI, Al-Hidayah, Al-Qura'an Terjemah Perkata, Banten: Penerbit Kalim, 2004.

Khaerani, ed, Islam dan Hegemoni Sosial, Jakarta: Media Cita, 2012.

Koentjaraningrat, Metode- Metode Penelitian Masyarakat, Jakarta: Gramedia, 1977.

Lajnah Pentashih Mushaf al-Qur'an Kementerian Agama RI, Tafsir Al-Qur'an Tematik, Jakarta: Penerbit Aku Bisa, 2012. 
Moch. Djamaluddin Achmad, Dakwah Islamiyah, Jombang: AlMuhibbin, t.t.

Muhammad Daud Gunawan, Pembangunan Berdimensi Keumatan, Bandung: Alfabeta, 2008.

M. Quraish Shihab, Tafsir Al-Misbab: Pesan, Kesan dan Keserasian AlQur'an, Jakarta: Lentera Hati, 2009. , Muk'zizat Al-Qur'an Ditinjau dari Aspek Kebahasaan, Isyarat Imiyyah dan Pemberitaan Ghaib, Jakarta, Mizan, 2007. , Wawasan Al-Qur'an, Bandung: Mizan, 2000.

Nasharudin Baidan, Tafsir Maudhu'i: Solusi Qur'ani atas Masalab Sosial Kontemporer, Yogyakarta: Pustaka Pelajar, 2001.

Pius A Partanto dkk, Kamus Ilmiah Popular, Surabaya: Arkola, 1994.

Piotr Sztompka, Sosiologi Perubahan Sosial, Jakarta: Prenada, 2011.

Ronald Robertson, Agama dalam Analisa dan Interpretasi Sosiologis, Jakarta: Rajawali Press, 1995.

Syarifuddin Jurdi, Sosioogi Islam dan Masyarakat Moderm, Jakarta: Prenada: 2010.

Soerjono Soekanto, Sosiologi Suatu Pengantar, Jakarta: PT. Raja Grafindo, 2003.

Soegiono, Metode Penelitian Kuantitatif, Kualitatif dan R\&D, Bandung: CV. Alfabeta, 2007.

Yayasan Obor Jakarta, Metode Penelitian Kepustakaan, Jakarta: Yayasan Obor Jakarta, 2003. 
Siti Badi'ah 